\title{
Automatic Versus Manual Solar Panel Cleaning for Remote Locations
}

\author{
Lisa Ann Lamont ${ }^{1, *}$ and Lana El Chaar ${ }^{2}$ \\ ${ }^{1}$ Transmission and Distribution Division, Mott MacDonald, Glasgow, UK \\ ${ }^{2}$ Power Generation Services, GE Power and Water, Dubai, UAE
}

\begin{abstract}
Photovoltaic solar technology is now being widely investigated for implementation in the UAE as a possible renewable energy source. Currently the main emphasis is on the accessible areas but remote locations are now being explored for the possibility of large scale deployment. However due to the environment and location certain measures such as regular cleaning must be considered to ensure the efficient operation of the PV panels. This paper investigates the cost of current developed cleaning technologies available in the Gulf region, highlights their advantages and disadvantages and the time needed to recoup initial investment.
\end{abstract}

Keywords: Solar Energy, Photovoltaic, Renewable Energy, Electricity Generation.

\section{INTRODUCTION}

Many companies in the Gulf region are looking for solutions to the problem of power in remote locations and have implemented photovoltaic (PV) technology with secondary batteries to secure this since it was found to be the most suitable solution for these areas [1]. Nevertheless such technology suffers today with lower efficiency as well as other issues which traditional electricity generation techniques do not see; hence it is vitally important to keep these modules running at their maximum output [2]. It has been widely proven in test systems that the accumulation of dust particles on the surface of the PV panels affects the output power generated in the same manner as clouds would [3-5]. PV outputs in various applications have been reduced due to two main factors which are dust and hard and soft particle shading which can come from bird droppings which can significantly reduce the PV output power, if not removed, hence causing a negative impact on the system's performance which is a critical issue for remote power generation.

Currently, one of the implemented methods to clean the panel and retrieve the maximum power generated by the panel is to implement manual cleaning but depending on the remoteness this can be expensive. Therefore, a proactive, cost effective solution is required to ensure cost efficiency for deploying this cleaning technology. In designing such a solution several factors need to be taken into consideration such as i) lack of distilled water, ii) power source accessibility due to the location, iii) space availability

*Address correspondence to this author at the Transmission and Distribution Division, Mott MacDonald, Glasgow, UK; Tel: +44(0) 141222 9162;

Fax: +44(0) 141221 2048; E-mail: Lisa.lamont@mottmac.com and iv) maintenance. To resolve some of these issues, the cleaning system should consume low power and require minimal maintenance. In this paper two alternative solutions to manual cleaning are presented and a cost comparison is completed.

\section{SOLAR ENERGY}

PVs are considered to be an environmentally friendly option and when operating do not produce $\mathrm{CO}_{2}$ emissions or any other pollutants making them a suitable technology for cutting carbon footprint and provides power to locations which otherwise would use a diesel generator. Such systems are suitable for basic electrical supplies for low power requirement and remote locations such as the Gulf desert which provides its own unique challenges.

However, no system is perfect and an issue with PVs is its degradation due to prolonged exposure to ultraviolet (UV) radiation which is a concern for long term operation [6]. Unfortunately, this is not the only problem, the effects of dust $[7,8]$ and loads on the system [9] are factors which should also be considered. A major issue that is currently being considered more often in the renewable energy field is the energy loss or panel damage which can occur due to natural staining or shading. Some suggested solutions to reduce the impact of the above mentioned concerns have been presented in the following references keeping in mind that the proposed methods are for large scale installations rather than single panels [10-14]. Currently in the Gulf region PV installations are formed by small numbers of modules, thus a small amount of shading can result in the whole supply being disabled. To ensure a reliable system, the designer must have an 
extended knowledge of photovoltaic theory and the possible issues and ensure they are addressed.

\section{PHOTOVOLTAIC MODULES}

A photovoltaic module is a combination of small solar cells which are the basic power conversion units. A photovoltaic system is the series/parallel connection of several PV modules in order to meet the current and voltage requirements. Photovoltaic energy conversion relies on the quantum nature of light where a flux of photons carries the energy

$E_{p h}(\Lambda)=\frac{h c}{\lambda}$

$h$ is the Planck constant, $c$ is the speed of light, and $\lambda$ is the wavelength of the earth's surface every second. "Because photovoltaic cells mainly convert to electricity photons of visible, ultraviolet and infrared light, i.e. photons of lower energy than X-rays, the external photo effect is not applicable to photovoltaic cells [15]."

Solar cells are p-n junctions which consist of doped semi-conductor material. Energy is transferred by photons falling within the junction, creating a current flow. Internal electric field at the junction causes voltage drop which is required in order for the PV cell to generate power. Photovoltaic systems offer substantial advantages over common power sources due to their reliability, durability, low maintenance cost, no fuel cost, modularity, safety and independence. However, they have some disadvantages including high initial cost, variability of available solar radiation, efficiency improvement and energy storage.

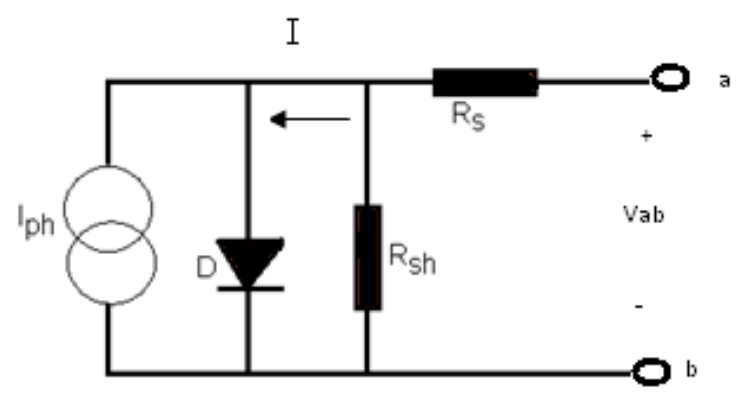

Figure 1: Standard model for photovoltaic cells.

PV modules are cells connected in series with two bypass diodes [16], with each solar cell represented by its equivalent circuit model, as illustrated in Figure $\mathbf{1}$ where, $I_{p h}$ is the photocurrent source, $D$ is a diode, $R_{s h}$ is a shunt resistance (normally large), $R_{s}$ is the series resistance (normally small) and $\mathrm{K}$ is Boltzmann's constant.
$I=I_{p h}-I_{S}\left[[e] \frac{\frac{V_{a b}+I R_{S}}{n k T}}{q}-1\right]-\frac{V_{a b}+I R_{S}}{R_{S h}}$

$\mathrm{I}_{\mathrm{ph}}$, the current source, produces a current which is proportional to the level of solar radiation landing on the cell.

$I_{p h}=C_{0} . E$

$\mathrm{E}$ is the irradiance level and $\mathrm{c}_{0}$ is a reflection coefficient [15]. When no load is connected, the current flows through the diode $D$ determining the solar cell's open voltage $V_{O C}$ [17]. The amount of irradiation colliding with the PV surface determines the short circuit current $\left(\mathrm{I}_{\mathrm{sc}}\right)$, and from the model shown above it is simply the light generated.

Due to the mismatching in PV modules in addition to the impact of non-uniform irradiation, cloud, cell damaging, partial shading and soiling, the output power generated by the PV system decreases extensively [10]. A solar cell can also be characterized by its maximum power point where the product $V_{m p} \times I_{m p}$ is at its maximum, where

$V_{m p}=V_{o c}-\frac{n k T}{q} \ln \left[\frac{V m p}{(n k T / q)}+1\right]$

The maximum device power which is noted as $P_{\max }$ can be obtained from highest point on the P-V curve. This power under strong sunlight $\left(1 \mathrm{~kW} / \mathrm{m}^{2}\right)$ is known as the peak power of the cell. Hence, solar cells are rated in terms of their peak watts $\left(W_{p}\right)$.

Moreover, in order to measure the junction quality and series resistance of the cell, a fill factor (FF) can be defined by:

$$
F F=\frac{V_{m p} I_{m p}}{I_{S C} V_{O C}}=\frac{P_{\max }}{I_{S C} V_{O C}}
$$

Obviously, the nearer the FF to unity, the higher the quality of the cell is. However, as the fill factor determines the output power of the cell, when considering the series resistance of the cell, the maximum power can be described by:

$$
P_{\max }=P_{m p}\left(1-\frac{I_{S C}}{V_{O C}} R_{s}\right)
$$


As mentioned earlier regarding the direct relationship between light available and amount of current produced, shading or staining may have a severe effect on the performance of the system by reducing the output power as much as $50 \%$ when the panel is shaded by as small an amount as $5 \%[10,14$, $16,18,19]$. Shading, which depends on the area and surroundings, can be classified into two types - Soft and Hard. Soft shading, which can block as much as $10 \%$ of the diffuse radiation from being captured by the cell, can be caused by local structures, telephone/electric poles, snow and fallen tree leaves. However, hard shading presents a more problematic issue as it prevents the cell absorbing either direct or diffuse light. When shading occurs, a significant reduction of the output power is noticed and two maxima appear on the PV curve. The first maximum is located very far from the normal maximum power point region and it is independent of the shaded area and irradiance while the second maximum depends on the shading scenario. In this case, the number of shaded cells determines the global maximum power of the panel.

Bird droppings are a prime example of natural hard shading. Not only does it block the solar radiation, it also stains the PV [20]. Both soft and hard shading will provide minimum current hence making the PV act as a resistive load. Dust accumulation, water stains (salt) or bird droppings can drastically affect the efficiency of the solar system by 10 to $25 \%$ [21, 22] with the PV surface being either partially or fully shaded (Figure 2). In either case, uneven illumination and reduction of sunlight reaching the PV cells is taking place, hence shading must then be eliminated or reduced. In addition, research has shown that deposition of various particles may negatively influence the "rate of heat transfer between the PV and the environment" [23].

\section{CURRENT SOLUTIONS}

In order to enhance the performance of the PV system, cleaning is required. Several methods have been discussed to eliminate the effect of solid particles accumulating on the surfaces of the PV's in order to maximize the solar radiation absorption by the panels. Various techniques have been considered and summarized in [24] but many more have been developed since this publication such as robotic devices [2, 25], coated glass [26, 27], oversizing [28] and manual [29]. Currently there are three viable solutions for the offshore environment of the United Arab Emirates (UAE):- manual cleaning which is traditionally used, PIC (Programmable Integrated Circuit) Microcontroller based cleaning [30] and PLC (Programmable Logic Controller) based cleaning [31]. The basic function of the two automated devices is shown in Figure 3.

Manual cleaning, which involves manpower, a pure water source and cleaning supplies, although a reasonable option in accessible locations due to the cheap labour and low initial costs, is a non-effective solution for remote areas mainly due to the transportation costs and time to travel to remote locations. Therefore, more automated systems such as the PIC or PLC based cleaning which requires less human intervention is more environmentally and economically favoured. These automated systems (Figure 3), although using different types of controllers for the cleaning, use the same principle to clean the PV panels. The main features of the process of these

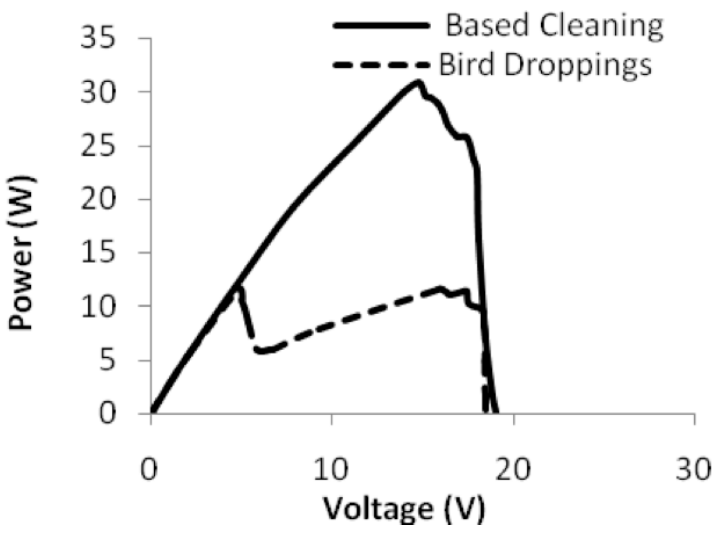

(b)

Figure 2: (a) Birds dropping on PV panel (b) Power-Voltage characteristics showing effect of shading due to droppings (measured by the authors). 


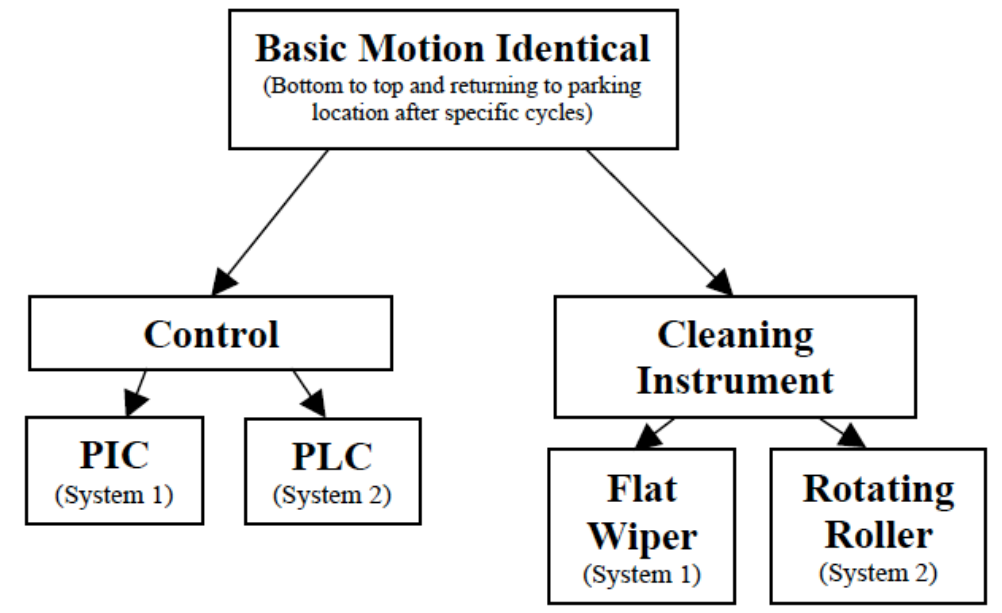

Figure 3: System description of PIC and PLC based cleaning systems.

cleaning systems are as follows but are further described in references $[30,31]$.

PIC based cleaning main features:-

- A solar powered water desalination

- Minimal cost with simple operation

- Daily cleaning initiated by means of a photodetector (detecting daylight)

- Water to wet the panel was provided by a desalination water system

- Wipers move in two rounds of movement from their initial position at the bottom of the panel

PLC based cleaning main features:-

- Cleaning is started by a 24 hour timer - time specified by the user

- Water storage tank is used for the desalinated water
- $\quad$ Roller blade is used to clean the panel not only moving up and down but also rotating

- Water from the tank is sprayed before the three cycles begin for cleaning

A detailed list of advantages and disadvantages of all options are summarized in Table 1.

Reference [32] interestly noted that for a PV panel automatic cleaning generates more output power than without an integrated mechanical cleaning system.

\section{RESULTS}

Initially, economics is one of the major constraints that is closely examined when designing and installing PV systems [28]. In addition to the initial capital cost, maintenance cost, system's lifetime, and salvage value, cleaning of PV systems is a primary issue to consider. The breakdown of the financial cost of the three possible cleaning systems is outlined in Tables 2 to 4. As the manual cleaning does not require any installation the only cost incurred is the maintenance

Table 1: Current Cleaning Solutions

\begin{tabular}{|c|c|c|c|}
\hline Cleaning Type & Manual cleaning & PIC based cleaning [30] & PLC based cleaning [31] \\
\hline \hline Advantage & No moving parts & $\begin{array}{c}\text { Low cost compared to PLC } \\
\text { Automated } \\
\text { Daily cleaning } \\
\text { 24 hours bird deterring }\end{array}$ & $\begin{array}{c}\text { Automated } \\
\text { Daily cleaning } \\
24 \text { hours bird deterring }\end{array}$ \\
\hline Disadvantage & Cost varies, depending on location and \\
& $\begin{array}{c}\text { manpower } \\
\text { Time consuming } \\
\text { Inefficient water usage }\end{array}$ & $\begin{array}{c}\text { Inefficient water usage } \\
\text { Moving parts }\end{array}$ & $\begin{array}{c}\text { Higher initial cost compared to } \\
\text { PIC } \\
\text { Moving parts } \\
\end{array}$ \\
& No feedback about specific time for cleaning & & Inefficient water usage \\
\hline
\end{tabular}


Table 2: Costing for Manual Cleaning

\begin{tabular}{|c|c|c|}
\hline $\begin{array}{l}\text { Description of Maintenance } \\
\text { (6 times a year) }\end{array}$ & Quantity & Cost (\$) per part \\
\hline Labours & 12 & 150 \\
\hline Materials & 6 & 275 \\
\hline Total Maintenance per year & & 3,450 \\
\hline
\end{tabular}

Table 3: Costing for PIC Based Cleaning

\begin{tabular}{|c|c|c|}
\hline Description of Installation & Quantity & Cost (\$) per part \\
\hline Labours & 4 & 150 \\
\hline Total - Initial Installation & & 1,150 \\
\hline Description of Design Cost & Quantity & Cost (\$) per part \\
\hline Nozzles & 2 & 4 \\
\hline Pipes & 5 meters & 2 \\
\hline Solar Heater & 1 & 68 \\
\hline Pumps & 2 & 19 \\
\hline Rail & 2 & 2.75 \\
\hline LED's & 2 & 3.5 \\
\hline Tank & 1 & 27 \\
\hline Buzzer & 1 & 12.25 \\
\hline PIC 18 and motor driver & 1 & 15 \\
\hline Aluminum Structure & 1 & 82 \\
\hline Total - Initial Investment & & 370.75 \\
\hline $\begin{array}{l}\text { Description of Maintenance } \\
\text { (2 times a year) }\end{array}$ & Quantity & Cost (\$) per part \\
\hline
\end{tabular}

and as with Table $\mathbf{3}$ and $\mathbf{4}$ it is the summation of the cost $(\$)$ per part times the quantity to provide the total maintenance per year. Table $\mathbf{3}$ and $\mathbf{4}$ not only include the maintenance per year they also include the total initial installation and the total initial investment both of which are calculated in the same manner as explained previously.

Table 5 incorporates not only the maintenance per year but also the initial outlay which is the total of the initial installation and the initial investment hence the total for 1 year is the summation of all these factors. It is evident from the calculations presented that the two automated systems would have a payback period of less than 1 year. Other factors should be considered with any cleaning mechanism specifically in a remote location. These concerns are related to the amount of water used as well as sustaining the maximum power generated. Determining solutions to these issues will have an impact on the system's economics. Since the efficiency as well as the electrical output decrease at high temperature [33], it is normally desirable to sustain 
Table 4: Costing for PLC Based Cleaning

\begin{tabular}{|c|c|c|}
\hline Description of Installation & Quantity & Cost (\$) per part \\
\hline Labours & 4 & 150 \\
\hline Engineer & 1 & 550 \\
\hline Total - Initial Installation & & 1,150 \\
\hline Description of Design Cost & Quantity & Cost (\$) per part \\
\hline Wood Structure & 1 & 125 \\
\hline PLC Controllers & 1 & 520 \\
\hline Metal Chain & 1 & 8 \\
\hline Pulleys & 2 & 7 \\
\hline Wiper and pump & 1 & 28.5 \\
\hline Buzzer & 1 & 16.5 \\
\hline Motion Sensor & 2 & 4 \\
\hline Limit Switch & 4 & 12.25 \\
\hline Nozzles & 2 & 4 \\
\hline Universal Motor & 1 & 49 \\
\hline Pipes & 1 & 14 \\
\hline Water Tank & 1 & 63 \\
\hline Wooden Tank Support & 1 & 14 \\
\hline Motor Driver and wires & 1 & 22 \\
\hline Total - Initial Investment & & 939 \\
\hline $\begin{array}{l}\text { Description of Maintenance } \\
\qquad(2 \text { times a year) }\end{array}$ & Quantity & Cost (\$) per part \\
\hline Labours & 4 & 150 \\
\hline Materials & 2 & 150 \\
\hline Total Maintenance per year & & 900 \\
\hline
\end{tabular}

Table 5: Comparison Over a 1 Year Period

\begin{tabular}{|c|c|c|c|}
\hline Cleaning Type & Initial Outlay & Maintenance per year & Total for 1 year \\
\hline \hline Manual cleaning & 0 & $3,450.00$ & $3,450.00$ \\
\hline PIC based cleaning & $1,520.75$ & 900.00 & $2,420.75$ \\
\hline PLC based cleaning & $2,089.00$ & 900.00 & $2,989.00$ \\
\hline
\end{tabular}

a low system temperature which is difficult in the UAE due to high peaks reached during summer months. Frequent cleaning could be a solution to maintain preferred temperature and this could definitely be achieved by the proposed automated cleaning mechanisms where a timer or command is used to clean the panels' surface. Pure water in the Gulf is expensive so the amount used with automated systems can be controlled compared with manual cleaning where limited control only is possible.

\section{CONCLUSION}

This paper presented a detailed cost comparative study for PV cleaning systems in the remote locations of the UAE region. It is well noted that an automated system is an important solution to overcome the problem of dust accumulation which was found to have a negative impact on the PV performance, hence effecting the efficient operation. The cost comparison proved that over an extended duration the automated 
system is more cost effective than the manual cleaning that is currently undertaken. However implementing such technology will require a high initial cost from the company.

\section{REFERENCES}

[1] Snyder RE. Solar power generator cuts offshore operating cost. World Oil 1973; 176(6): 81-83.

[2] Anderson M, Grandy A, Hastie J, Sweezy A, Ranky R, Mavroidis C, Markopoulos Y. Robotic device for cleaning photovoltaic panel arrays, Reference: Available from: http://www.coe.neu.edu/Research/robots/papers/CLAWAR09 .pdf

[3] Mohandes B, El Chaar L, Lamont LA. Application study of $500 \mathrm{~W}$ photovoltaic (PV) system in the UAE. J Appl Solar Energy 2009; 45(4): 242-47. http://dx.doi.org/10.3103/S0003701X09040057

[4] Al Hanai T, Bani Hashem R, El Chaar L, Lamont LA. Study of a $900 \mathrm{~W}$, thin-film, amorphous silicon PV system in a dusty environment, Proceedings of International Conference on Renewable Energy: Generation and Application. Al Ain, UAE March 8-10, 2010.

[5] Kimber A. The Effect of Soiling on Photovoltaic Systems Located in Arid Climates, Proceedings of 22nd European Photovoltaic Solar Energy Conference, Milan, Italy, September 3-7, 2007.

[6] Chakravarty BC, Das BK, Arora NK, Basu PK, Vaishya JS. Degradation of solar cells made of upgraded metallurgical grade silicon. Solar Energy Materials Solar Cells 1992; 26(4): 339-43. http://dx.doi.org/10.1016/0927-0248(92)90053-R

[7] Al-Hasan AY, Ghoneim AA. A new correlation between photovoltaic panel's efficiency and amount of sand dust accumulated on their surface. Int J Sustainable Energy 2005; 24(4): 187-97.

http://dx.doi.org/10.1080/14786450500291834

[8] El-Shobokshy MS, Mujahid A, Zakzouk AKM. Effects of dust on the performance of concentrator photovoltaic cells. IEE Proc I Solid-State Electron Devic 1985; 132(1): 5-8.

[9] Steffens F. Solar energy: battery energy storage control. J Power Sourc 1991; 35(1): 1-20. http://dx.doi.org/10.1016/0378-7753(91)80001-E

[10] Karatep E, Hiyama T, Boztepe M, Çolak M. Voltage based compensation system for PV generation system under partially shaded insolation conditions. Energy Conversion Management 2008; 49(8): 2307-16. http://dx.doi.org/10.1016/j.enconman.2008.01.012

[11] Uchida D, Otani K, Kurokawa K. Evaluating the effect of shading factor by fitting a clear day pattern obtained from hourly maximum irradiation data. Solar Energy Mater Solar Cells 2001; 67(1): 19-28.

http://dx.doi.org/10.1016/S0927-0248(00)00321-4

[12] Drif M, Perez PJ, Aguilera J, Aguilar JD. A new estimation method of irradiance on a partially shaded PV generation in grid-connected photovoltaic systems. Renewable Energy 2008; 33(9): 2048-56.

http://dx.doi.org/10.1016/j.renene.2007.12.010

[13] Alonso-Garcia MC, Ruiz JM, Herrmann W. Computer simulation of shading effects in photovoltaic arrays. Renewable Energy 2006; 31(12): 1986-93. http://dx.doi.org/10.1016/j.renene.2005.09.030

[14] Herrmann W, Wiesner W. Modelling of PV modules the effects on non-uniform irradiance on performance measurements with solar simulators, Proceedings of $16^{\text {th }}$ European Photovoltaic Solar Energy Conference, Glasgow, UK, May 1-5, 2000.
[15]

Markvart T. Solar Electricity, John Wiley \& Sons, Chichester 2001.

[16] Karatepe E, Boztepe M, Colak M. Development of a suitable model for characterizing photovoltaic arrays with shaded solar cells. Solar Energy 2007; 81(9): 77-92.

[17] Ubisse A, Sebitosi A. A new topology to mitigate the effect of shading for small photovoltaic installations in rural subSaharan Africa. Energy Conversion Management 2009; 50(7): 1797-801.

http://dx.doi.org/10.1016/i.enconman.2009.03.016

[18] Pang $\mathrm{H}$, Close J, Lam L. Study on effect of urban pollution to performance of commercial copper indium diselenide modules, Proceedings of 4th World Conference on Photovoltaic Energy Conversion, Hawaii, USA, May 7-12, 2006.

[19] Sharma AK, Dwivedi R, Srivastava SK. Performance analysis of a solar array under shadow condition. IEE Proceedings Part G: Circuit, Devices \& Systems 1991; 138(1): 301-306.

[20] Kovach A, Schmid J. Determination of energy output loss due to shading of building-integrated photovoltaic arrays using a ray tracing technique. Solar Energy 1996; 57(2): 11724.

\section{http://dx.doi.org/10.1016/S0038-092X(96)00066-7}

[21] Goossens D, Kerschaever EV. Aeolian dust deposition on photovoltaic solar cells: the effects of wind velocity and airborne dust concentration on cell performance. Solar Energy 1999; 66(4): 277-89. http://dx.doi.org/10.1016/S0038-092X(99)00028-6

[22] Kobayashi S, Tomonori I, Kobayashi H, Yamada K, Yachi T. Degradation of output characteristics of a small photovoltaic module due to dirt spots. Proceedings of Intelec 2005, Berlin, Germany, Sept 18-22, 2005.

[23] Kaldellis JK, Fragos P, Kapsali M. Systematic experimental study of the pollution deposition impact on the energy yield of photovoltaic installations. Renewable Energy Article in Press 2011.

http://dx.doi.org/10.1016/j.renene.2011.03.004

[24] Lamont LA, El Chaar L. Enhancement of a stand-alone photovoltaic system's performance: reduction of soft and hard shading. J Renewable Energy 2011; 36(4): 1306-10. http://dx.doi.org/10.1016/j.renene.2010.09.018

[25] Heliotex, Automatic solar cleaning systems, www.solarpanelcleaningsystems.com/, accessed 10/05/2011.

[26] Verma LK, Sakhuja M, Danner AJ, Yang H, Zeng HC, Bhatia $\mathrm{CS}$. Self-cleaning and antireflective packaging glass for solar modules. Renewable Energy 2011; 36(9): 2489-93. http://dx.doi.org/10.1016/j.renene.2011.02.017

[27] Georgia Institute of Technology, Self-cleaning, low-reflectivity treatment boosts efficiency for photovoltaic cells, http://www. Physorg.com/news157137842.html, accessed 10/05/2011.

[28] Sharma VK, Colengelo A, Spagna G. Photovoltaic technology: basic concepts, sizing for a stand-alone photovoltaic system for domestic applications and preliminary economic analysis. Energy Conversion Management 1995; 36(3): 161-74. http://dx.doi.org/10.1016/0196-8904(94)00065-8

[29] Sol-Taic-Solar, Nationwide cleaning services, http://www.soltaicsolar.com/, accessed 10/05/2011.

[30] Al-Qubaisi E, Al-Ameri M, Al-Obaidi A, Rabia M, El Chaar L, Lamont LA. Microcontroller based dust cleaning system for a standalone photovoltaic system, Proceedings of Electric Power and Energy Conversion Systems, Sharjah, UAE, Nov 10-12, 2009.

[31] Al-Dhaheri S, Lamont LA, El Chaar L, Al-Ameri O. Automated design for boosting photovoltaic (PV) performance offshore, Proceedings of Electric Power and Energy Conversion Systems Transmission and Distribution Conference and Exposition, New Orleans, USA, April 19-22, 2010. 
[32] Ju F, Fu X. Research on Impact of Dust on Solar Photovoltaic (PV) Performance, Proceeding of International Conference on Electrical and Control Engineering (ICECE), Yichang, China, 16-18 Sep, 2011.
[33] Krauter S. Increased electrical yield via water flow over the front of photovoltaic panels. Solar Energy Materials Solar Cells 2004; 82(1-2): 1313-37.

http://dx.doi.org/10.1016/j.solmat.2004.01.011 